\title{
Matriconditioning of Vegetable Seeds to Improve Stand Establishment in Early Field Plantings
}

\author{
Anwar A. Khan', James D. Maguire ${ }^{2}$, George S. Abawi ${ }^{3}$, and Satriyas Ilyas ${ }^{4}$ \\ New York State Agricultural Experiment Station, Cornell University, Geneva, NY 14456
}

Additional index words. Daucus carota, Lycopersicon esculentum, Capsicum annuum, Phaseolus vulgaris, osmoconditioning, field emergence

\begin{abstract}
A matriconditioning procedure based on the matric properties of Micro-Cel $\mathbf{E}$ and expanded vermiculite \#5 has proved effective in improving seedling emergence in growth chambers. The major objectives of this study were to examine some physical characteristics of the carriers and their effectiveness as preplant conditioning media in improving stand establishment of vegetable seeds in field plantings. Carrier characteristics included no detectable solute or osmotic potential, low electrical conductivity $(0.48-0.04 \mathrm{mmho} / \mathrm{cm})$, high water-retaining capacity $(450 \%$ to $600 \%$ ), a pH range of 7.0 to 8.4, and ability to effectively control seed hydration (conditioning) at low matric potential. The seed : carrier : water ratio for seed conditioning ranged from 1:0.3-0.5:1-2 (by weight). In a field trial, conditioning of 'Long Imperator' and 'Nantes' carrot (Daucus carota var. sativus Hoffm.) seeds reduced the time to $10 \%$ of final emergence $\left(T_{10}\right)$ by 2.6 to 2.8 days and to $50 \%$ of final emergence $\left(T_{50}\right)$ by 2.1 to 3.0 days. Conditioning increased the final emergence percentage by $39 \%$ in 1-year-old 'Long Imperator' compared to $150 \%$ in 4-year-old 'Nantes' seeds. In another field trial, the effect of conditioning on stand establishment was evaluated in 'Jackpot' tomato (Lycopersicon esculentum Mill.), 'California Wonder' pepper (Capsicum annuum L.), and 'BBL 47' snap bean (Phaseolus vulgaris) seeds. In tomato, conditioning reduced the $T_{10}$ by 0.9 day, had no effect on $T_{50}$, and increased the emergence percentage by $86 \%$. In pepper, conditioning reduced the $T_{10}$ and $T_{50}$ by 1.5 days and increased the percentage emergence by $30 \%$. In snap bean seeds, conditioning in Micro-Ccl $E$ reduced the $T_{10}$ and $T_{50}$ by 0.8 day but adversely affected the percentage emergence. Further reductions in $T_{10}$ and $T_{50}(1.2$ and 1.6 days, respectively) and restoration of percentage emergence to control level occurred upon addition of $0.001 \mathbf{~ m M ~ G A}_{3}$ during conditioning. Fungicides added to carrot, tomato, and pepper seeds, with or without conditioning, showed no additional improvements and, in a few cases, adversely affected emergence. A preplant conditioning in Micro-Ccl $\mathrm{E}$, alone or in combination with $\mathbf{G A}_{3}$, smears to be a viable alternative to conditioning! seeds in liquid carriers. Chemical name used: gibberellic acid $\left(\mathrm{GA}_{3}\right)$
\end{abstract}

Osmoconditioning or priming of seeds in solutions of low water potential, e.g., polyethylene glycol (PEG) and salts, has been used extensively as a preplant seed treatment to reduce germination or seedling emergence time, synchronize emergence, and improve stand establishment and yield (Bradford, 1986; Heydecker and Coolbear, 1977; Khan, 1991; Khan et al., 1978). A preplant seed conditioning has also been achieved by mixing seeds with moist solid or semisolid carriers (e.g., vermiculite, expanded calcined clay, Agro-Lig, sodium polypropionate gel, synthetic calcium silicates) (Bennett and Waters, 1987; Callan et al., 1990; Khan et al., 1990; Kubik et al., 1988; Parera and Cantliffe, 1990; Peterson, 1976; Taylor et al., 1988; Zuo et al., 1988). Postplant conditioning of beet seeds in moist soil microenvironment in the field has been achieved by incorporating PEG into solid material used for seed pelleting, as indicated by improved emergence and yield (Khan and Taylor, 1986).

Hydration or conditioning of seeds can be regulated by osmotic and/or matric components of the carrier matrix water potential. The water potential component(s) of the carrier can be

\footnotetext{
Received for publication 11 Feb. 1991. This research was supported, in part, by grants from the Ferry Morse Seed Co. and the New York Snap Bean Research Assn. We gratefully acknowledge the gifts of Micro-Ccl E from Manville, Denver expanded vermiculite \#5 from W.R. Grace \& Co., Cambridge, Mass.; tomato and carrot seeds from Ferry Morse Seed Co., Modesto, Calif.; pepper seeds from PetoSeed Co., Saticoy, Calif.; and snap bean seeds from Asgrow Seed Co., Kalamazoo, Mich. The cost of publishing this paper was defrayed in part by the payment of page charges. Under postal regulations, this paper therefore must be hereby marked advertisement solely to indicate this fact.

${ }^{1}$ Professor, Dept. of Horticultural Sciences.

${ }^{2}$ Visiting Fellow, Dept. of Horticultural Sciences. Present address: Dept. of Agronomy and Soils, Washington State Univ., Pullman, WA 99164. ${ }^{3}$ Professor, Dept. of Plant Pathology.

${ }^{4}$ Graduate Student, Dept. of Horticultural Sciences.
}

predominantly matric Bennett and Waters, 1987; Khan et al., 1990; Kubik et al., 1988), osmotic (Taylor et al., 1988), or a combination of the two (Khan and Taylor, 1986; Peterson, 1976). Seed conditioning with solid carriers devoid of osmotic solutes and with high water adsorptive capillary forces, such as expanded vermiculite \#5 (W.R. Grace and Co., Cambridge, Mass.) and Micro-Ccl E (Manville, Denver), has been referred to as "matriconditioning" (Khan, 1991; Khan et al., 1990). As the water-holding capacity and bulk density of solid carriers differ greatly, the amount of carrier relative to seed and water used for optimum conditioning have differed greatly.

Few field trials on seeds conditioned with moist solid carriers have been reported, and these are limited to large-seeded vegetables. A 3-day conditioning (moisturizing) of sweet corn seeds with moist vermiculite improved the emergence in early planting, but had little effect on final emergence (Bennett and Waters, 1987). A 4-day conditioning (solid matrix priming) of pea and sweet corn seeds with Agro-Lig (American Colloid Co., Arlington Heights, 111.), a Leonardite shale, had an inconsistent effect on emergence; the treatment, however, was effective in improving emergence when combined with the fungal strains of Trichoderma harzianum (Rifai) (Harman et al., 1989). Conditioning (the duration of conditioning and the identity of the solid carrier used were not reported) of sweet corn with a solid carrier in the presence of chlorine bleach improved the rate and percentage of emergence (Parera and Cantliffe, 1990). In a preliminary report, beet seeds conditioned with Micro-Ccl E and expanded vermiculite \#5 showed a significant improvement in stand establishment (Khan et al., 1990).

We report here some physical characteristics of the solid carriers Micro-Ccl E and expanded vermiculite \#5 and their effestiveness as seed conditioning media in improving stand establishment of vegetable seeds in early field plantings. 


\section{Materials and Methods}

Seeds. Seeds of 'Jackpot' tomato, 'Long Imperator' carrot, 'California Wonder' pepper, and 'Bush Blue Lake 47' snap bean obtained in 1989 (germination > 90\%) from seed companies and stored at $28 \%$ relative humidity $(\mathrm{RH})$ and $7 \mathrm{C}$ were used for various trials. One lot of low-vigor 'Nantes' carrot seeds (with slow rate of germination but with $91 \%$ final germination) stored at room temperature (varied from 25 to $30 \mathrm{C}$ ) in paper envelopes for 4 years was also included in the trials.

Application of protestants and hormone to seeds For nonconditioned tomato and pepper seeds, tetramethyylthiuram disulfide (thiram) $75 \mathrm{~W}$ was applied at the rate of $54 \mathrm{mg} \cdot 16 \mathrm{~g}$ and $40 \mathrm{mg} \cdot 16 \mathrm{~g}^{-1}$ of seeds, respectively, with the aid of 0.5 $\mathrm{ml}$ of 1.570 methylcellulse (Methocel). For nonconditioned carrot seeds, a combination of thiram $75 \mathrm{~W}$ and $\mathrm{N}$-(2,6-dimethylphenyl)-N-(methoxyacetyl) alnine methyl ester [metalaxyl (Apron)] $25 \mathrm{~W}$ at the rate of $20 \mathrm{mg} \cdot 16 \mathrm{~g}^{-1}$ and $30 \mathrm{mg} \cdot 16 \mathrm{~g}^{-1}$ seed, respectively, were applied via $3.2 \mathrm{ml}$ of $1.5 \%$ methylcellulose. Snap bean seeds were commercially treated with N-trichloromethylthio-4-cyclohexane-1,2-dicarboximide (captan) 50W, they were additionally treated with the insecticide $\mathrm{O}$, O-diethyl O-(3,5,6-trichloro-2-pyridinyl) phosphorothioate [chlorpyrifos (Lorsban)] $50 \mathrm{~W}$ at the rate of $212 \mathrm{mg} \cdot 170 \mathrm{~g}^{-1}$ seeds via 1.1 $\mathrm{ml}$ of $1.5 \%$ methylcellulose. The amounts and the types of protestants applied to various seeds during conditioning were identical to those applied to nonconditioned seeds, except that they were applied via aqueous suspension and were mixed with the seed and the carrier at the time of conditioning (see below). Only snap bean seeds were treated with $\mathrm{GA}_{3}(0.001$ or 0.002 $\mathrm{mm}$ ), which was applied only during conditioning (see below). Preliminary screening in peat-lite mix established the levels of $\mathrm{GA}_{3}$ to be added during conditioning with Micro-Ccl E and expanded vermiculite \#5 for optimal effects. This hormone was previously reported to be effective when applied during conditioning to improve emergence of soybean seeds (Khan et al., 1980/81).

Determination of physical characteristics of carriers. Most studies were conducted with Micro-Ccl E (Table 1), a synthetic calcium silicate that is produced by hydrothermal reaction of diatomaceous silica, hydrated lime, and water. Expanded vermiculite \#5 (Table 1), produced by exfoliating vermiculite (a hydrated aluminum silicate), was used only with snap bean seeds. Electrical conductivity and $\mathrm{pH}$ were determined in a $10 \%$ (w/v) water slurry by a digital conductivity meter. Microsmette (model 5004; Precision Systems, Natick, Mass.) was used to determine osmotic or solute potential in a $10 \%(\mathrm{w} / \mathrm{v})$ water extract. Moisture-retaining capacity of Micro-Ccl E and expanded vermiculite \#5 was compared with several other materials [Agro-Lig; Celite 400, a grade of diatomaceous silica (Manville); and Collamer silt loam]. The relationship between water retained by the solids and matric potential was determined by a standard procedure (Olson, 1979).

Mum-conditioning of seeds. Seeds of pepper, tomato, and carrot were first soaked for $\approx 5 \mathrm{~min}$ in a predetermined amount of water, solution, or suspension of chemicals in a 0.5 -liter glass jar; the carrier was then added and thoroughly mixed with the moist seeds. Snap bean seeds were added directly to previously moistened carrier in 4-liter polyethylene jars and gently mixed to avoid injury. The jars were loosely capped and transferred to $15 \mathrm{C}$ and $\approx 60 \% \mathrm{RH}$ in light for conditioning. The seed : carrier : water ratio [by weight (in grams)] used for seed conditioning, the duration of conditioning, and the water content of the seed and carrier at the end of conditioning for various
Table 1. Characteristics of Micro-Ccl E and expanded vermiculite $\# 5$, the solid carriers used for seed matriconditioning

\begin{tabular}{|c|c|c|}
\hline Characteristics & Micro-Ccl E & $\begin{array}{c}\text { Expanded } \\
\text { vermiculite \#5 }\end{array}$ \\
\hline Water absorption ( $\%$ by wt $)^{2}$ & 550 & 410 \\
\hline Bulk density $\left(\mathrm{kg} \cdot \mathrm{m}^{-3}\right)^{\mathrm{z}}$ & 88 & 162 \\
\hline Surface area $\left(\mathrm{m} \cdot \mathrm{g}^{-1}\right)^{\mathrm{z}}$ & 95.0 & 11.4 \\
\hline $\begin{array}{l}\% \text { Particles retained (Tyler } \\
\text { method) })^{z}\end{array}$ & & \\
\hline 325 mesh & 7.0 & --- \\
\hline 100 mesh & $\ldots$ & $80-100$ \\
\hline 28 mesh & --- & $0-5$ \\
\hline $\mathrm{pH}, 10 \%$ water slurry & 8.4 & 7.0 \\
\hline $\begin{array}{l}\text { Conductivity }(\mathrm{mmho} / \mathrm{cm}) \text {, } \\
10 \% \text { water slurry }\end{array}$ & 0.48 & 0.04 \\
\hline $\begin{array}{l}\text { Osmotic potential (MPa), } \\
10 \% \text { extract }\end{array}$ & Nondetectable & Nondetectable \\
\hline
\end{tabular}

"Data from "Micro-Ccl Synthetic Calcium Silicate Functional Fillers" (Bul. FF-427, 1985), Manville, P.O. Box 5108, Denver, CO 80217; and "Vermiculite, The Mineral for the '80's" (Bul. V102, 1983) and "Specialty Vermiculite" (Bul. V001, 1990), W.R. Grace and Co., 62 Whitmore Ave., Cambridge, MA 02140.

seed types were determined (Table 2). Water taken up by the seed at the end of conditioning was determined by rapidly rinsing the seed with water to remove the carrier adhering to the seed surface, blotting the seeds dry, and then weighing them. Water taken up by the carrier was the difference between the total amount of water added and the amount absorbed by the seed plus the amount lost by evaporation (ranged from 270 to $3 \%$ of the total amount of water added). A quick rinse did not appear to contribute significantly to the water absorbed by the seed during conditioning. This assumption was supported by the similarity of distribution of water between seeds and the carrier at the end of conditioning, whether the moist seeds (carrot, pepper, and tomato) were mixed with the carrier or kept separate from the carrier by a semipermeable membrane during conditioning; the latter procedure permitted weighing of seeds directly without rinsing following conditioning (Khan and Maguire, 1990).

Pesticides and/or hormone (GAS) were also applied during conditioning; in such cases, water in the conditioning mixture was replaced by the same amount of suspension or solution of chemicals (hormone and/or pesticide). Carrot, tomato, and pepper seeds were dried by forced air at $25 \mathrm{C}$ for $2 \mathrm{~h}$ without removing Micro-Ccl E; the loose carrier that came off the seeds was removed by sieving. These seeds were stored at $7 \mathrm{C}$ and $28 \% \mathrm{RH}$ for 24 to $48 \mathrm{~h}$ in open paper envelopes before field planting. The moisture contents of these seeds were presumed to range from $6 \%$ to $8 \%$. (A rapid rinse followed by $2 \mathrm{~h}$ of airdrying and 24 to $48 \mathrm{~h}$ of storage at $7 \mathrm{C}$ and $28 \% \mathrm{RH}$ reduced the seed water content to $6 \%$ to $8 \%$.) Snap bean seeds were sieved to separate them from Micro-Ccl E and expanded vermiculite and were planted in the field without drying.

Field emergence. In 1990 field trials, the effects of various seed treatments were evaluated by planting seeds in Lima silt loam (fine-loamy, mixed, mesic Glossoboric Hapludolf). Carrot seeds were planted on 1 May and those of tomato, pepper, and snap bean on 1 June 1990 in 5-m rows, $75 \mathrm{~cm}$ apart, with 100 seeds/row at a depth of $2.5 \mathrm{~cm}$ (tomato, pepper, and carrot) and $5 \mathrm{~cm}$ (snap bean) using a cone or a flex seeder. Treatments were replicated six times in a randomized complete block design. Seedling emergence was monitored at 1-to 2-day intervals after 
Table 2. Type of seeds and carriers used, seed : carrier: water ratio (by weight), duration of matriconditioning, and the moisture equilibrium water content of seed and carrier at the end of seed conditioning.

\begin{tabular}{|c|c|c|c|c|c|}
\hline \multirow[b]{2}{*}{ Seed/cultivar } & \multirow[b]{2}{*}{ Carrier } & \multirow{2}{*}{$\begin{array}{c}\text { Seed : carrier : } \\
\text { water ratio }\end{array}$} & \multirow{2}{*}{$\begin{array}{c}\text { Duration of } \\
\text { conditioning } \\
\text { (days) }\end{array}$} & \multicolumn{2}{|c|}{$\begin{array}{c}\text { Water content } \\
(\%)\end{array}$} \\
\hline & & & & Seed $^{2}$ & Carrier $^{y}$ \\
\hline $\begin{array}{l}\text { Jackpot tomato } \\
\text { California Wonder }\end{array}$ & Micro-Cel E & $16: 4.8: 22$ & 7 & 71 & 190 \\
\hline $\begin{array}{l}\text { pepper } \\
\text { Long Imperator }\end{array}$ & Micro-Cel E & $16: 4.8: 22$ & 7 & 69 & 201 \\
\hline cairol & Micro-Cel E & $16: 8: 32$ & 7 & 72 & 232 \\
\hline BBL 47 snap bean & $\begin{array}{l}\text { Micro-Cel E } \\
\text { Expanded } \\
\text { yermiculite \#5 }\end{array}$ & $20: 8: 26$ & 3 & 55 & 175 \\
\hline
\end{tabular}

${ }^{2}$ Initial moisture content of seeds, $5 \%$ to $7 \%$.

'Initial moisture contents of Micro-Cel $\mathrm{E}=4.3 \%$ and expanded vermiculite $\# 5=0.1 \%$.

planting. The maximum and minimum daily temperatures at a $5-\mathrm{cm}$ soil depth and daily precipitation during the period of seedling emergence following plantings were recorded (Fig. 1). The time to $10 \%\left(\mathrm{~T}_{10}\right)$ and $50 \%\left(\mathrm{~T}_{50}\right)$ of final emergence were computed from the emergence data. Analysis of variance (ANOVA) was used to determine the statistical significance of mean differences in $T_{10}$ and $T_{50}$ of final emergence and final emergence percentage.

\section{Results and Discussion}

Physical characteristics of the carriers. The relationship between the water-holding capacity and matric potential of the solids varied substantially (Fig. 2). Micro-Ccl E, expanded vermiculite, and Celite 400 were saturated at $600 \%, 450 \%$, and $370 \%$, respectively, of their own weight in water (these values are close to water absorption values shown in Table 1 from technical bulletins), while Agro-Lig and the Collamer silt loam required only $40 \%$ to $50 \%$ water for saturation. As Micro-Cel $\mathrm{E}$ and expanded vermiculite had no detectable solute or osmotic potential (the same is true for Celite 400; A.A.K., unpublished data) (Table 1), these carriers must depend on their matric or

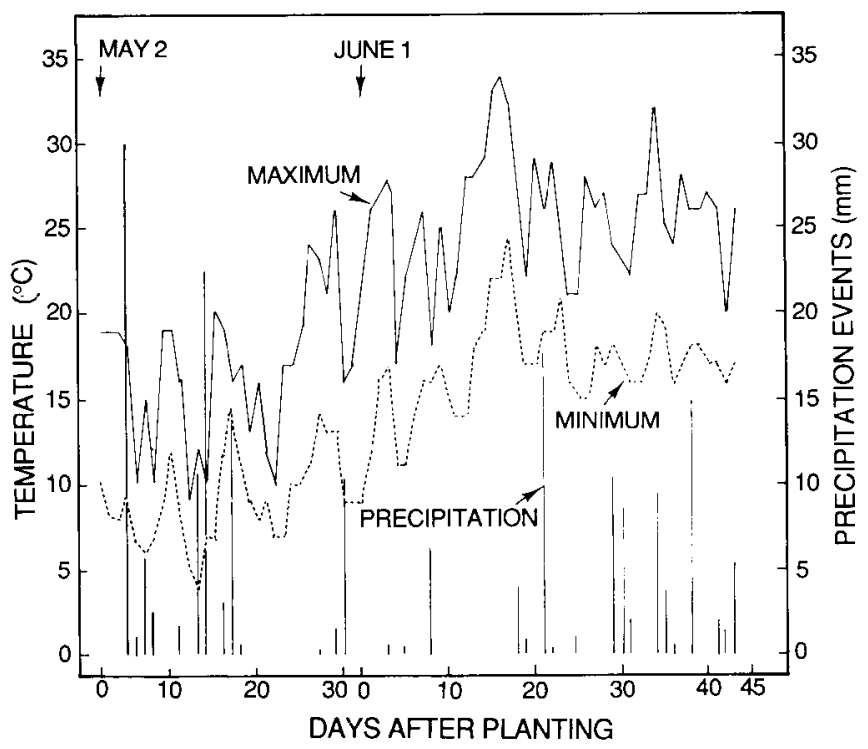

Fig. 1. Daily maximum and minimum temperatures and precipitation events during seedling emergence. Carrot seeds were planted on 2 May and tomato, pepper, and snap bean on 1 June 1990 as shown by arrows.

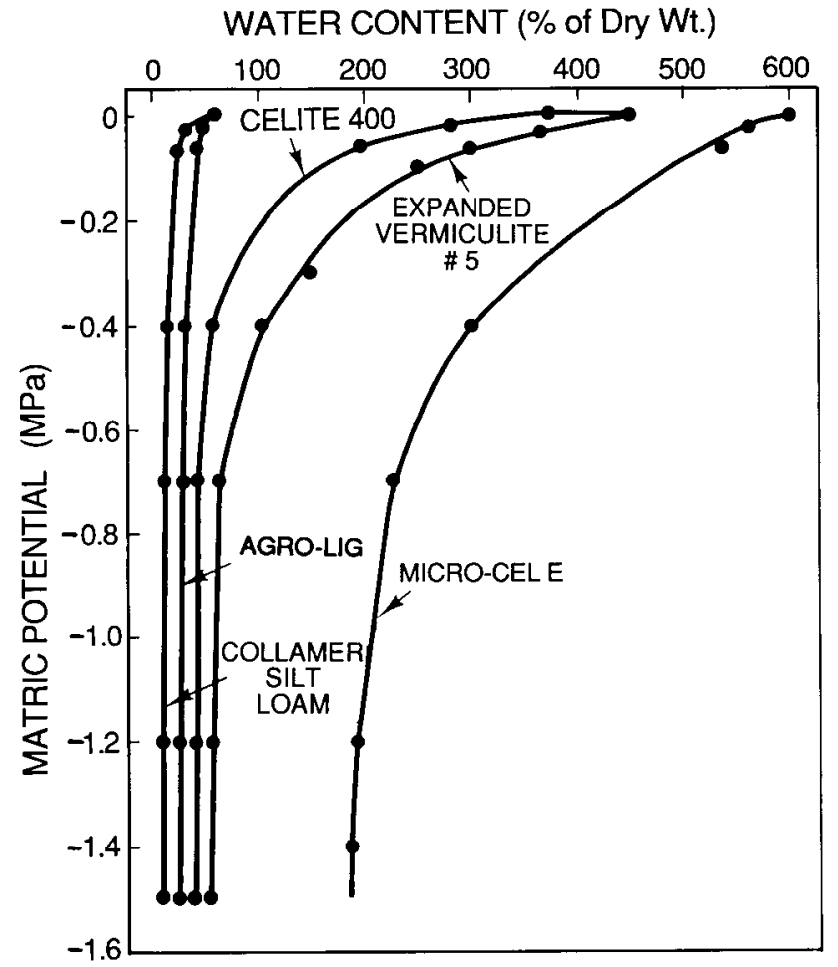

Fig. 2. Relationship between water content and matric potential of various solid materials.

surface active properties to control seed hydration during conditioning. This conclusion is consistent with the large surface area, high porosity, and diverse particle size and structure of Micro-Cel E and expanded vermiculite (Khan et al., 1990) (Table 1).

It is evident from the curves in Fig. 2 that a small decrease in the water content (e.g., by evaporation) of Micro-Cel E or expanded vermiculite would not greatly influence the matric potential of the carrier or the moisture equilibrium between the carrier matrix and the seed during prolonged periods of seed conditioning. The carrier matric potential needed for conditioning of a seed can be estimated by first determining the water content of the carrier in equilibrium with the seed at the end of conditioning (Table 2) and then relating the water content to the matric potential (Fig. 2). Water content of Micro-Ccl E and expanded vermiculite at the end of conditioning corresponded with 0.4 to $1.5 \mathrm{MPa}$ matric potential, a range known to be effective in seed conditioning. 


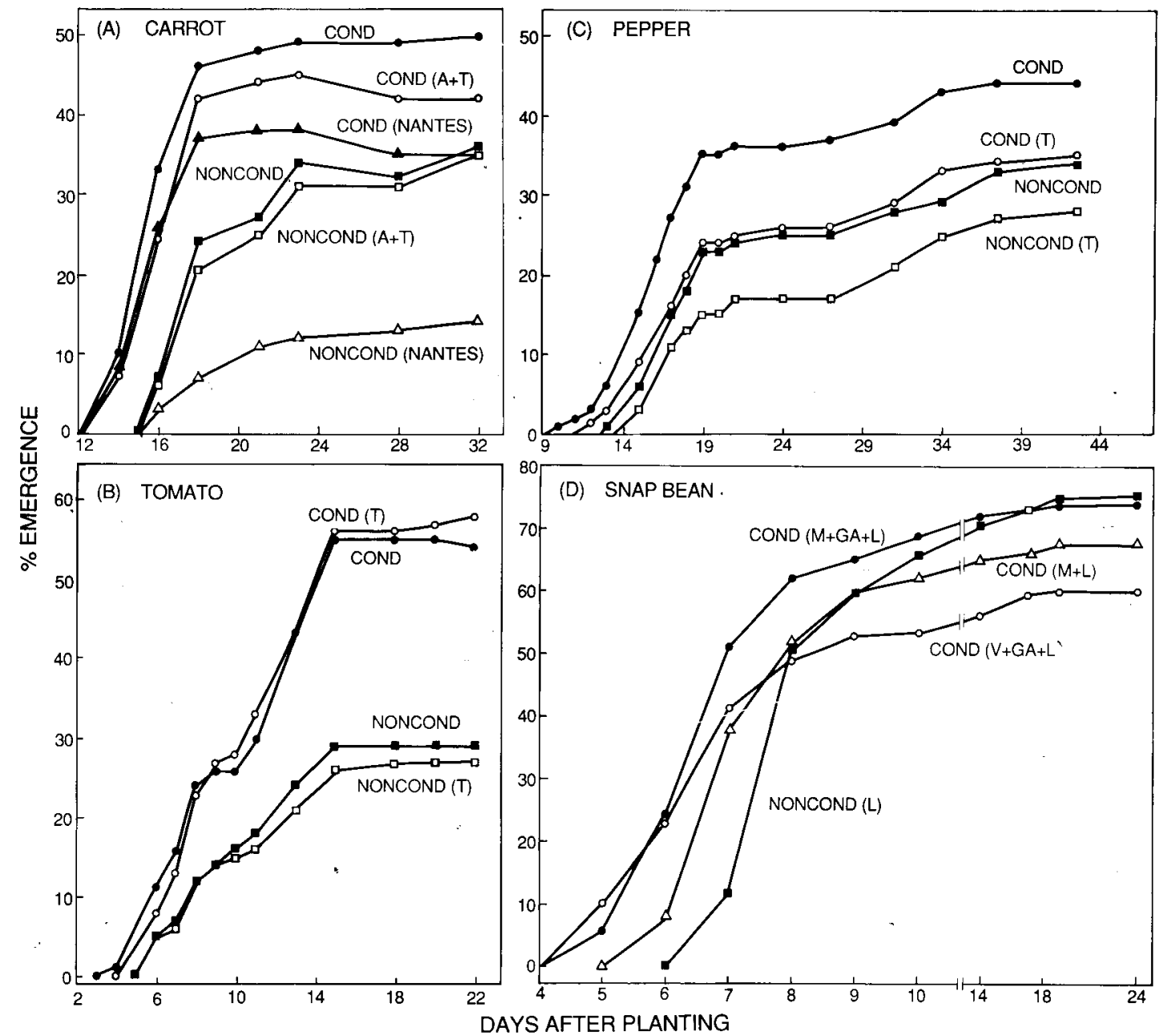

Fig. 3. Field emergence of vegetable seeds with or without matriconditioning and with or without chemical treatments. All seeds were matriconditioned with Micro-Ccl E; snap bean seeds were conditioned additionally with expanded vermiculite \#5. See Fig. 1 for planting dates. Cond $=$ conditioning in Micro-Cel E. Cond $(\mathrm{T})=$ conditioning in Micro Cel E plus thiram. Cond $(\mathrm{A}+\mathrm{T})=$ conditioning in MicroCel E plus Apron plus thiram. Cond $(\mathrm{M}+\mathrm{L})=$ conditioning in Micro-Ccl $\mathrm{E}$ plus Lorsban. Cond $(\mathrm{M}+\mathrm{GA}+\mathrm{L})=$ conditioning in Micro-Ccl E plus $0.001 \mathrm{~mm} \mathrm{GA}_{3}$ plus Lorsban. Cond $(\mathrm{V}+\mathrm{GA}+\mathrm{L})=$ conditioning in expanded vermiculite \#5 plus 0.002 mu GA ${ }_{3}$ plus Lorsban. Noncond $=$ untreated seeds. Noncond $(\mathrm{L})=$ dry seeds treated with Lorsban. Noncond $(\mathrm{T})=$ dry seeds treated with thiram. Noncond $(\mathrm{A}+\mathrm{T})=$ dry seeds treated with Apron plus thiram. 'Nantes' on some curves in A indicates older carrot seeds; other curves in this figure are of newer 'Long Imperator' carrot seeds. See Table 2 for statistical evaluation of emergence criteria.

In a carrier such as Agro-Lig, a small decrease in the water content by evaporation or absorption by the seed during conditioning would greatly alter its matric potential. This feature might explain why carriers with relatively low water-holding capacities are required in large quantities to meet the water requirements of seed for conditioning (Kubiket al., 1988; Taylor et al., 1988). Taylor et al. (1988) found conditioning of vegetable seeds with moist Agro-Lig to depend largely on osmotic solutes contained in the carrier. At $60 \%$ to $95 \%$ of water relative to the carrier (above the saturation level of Agro-Lig) used by these workers to condition vegetable seeds, the matric potential would be negligible (Fig. 2) and conditioning would be achieved by osmotic solutes in the carrier matrix. This situation may be analogous to osmoconditioning in a solution of salt or PEG on saturated filter paper or sand with negligible or zero matric potential.

Field emergence. A large difference in the final percent emergence $(14 \%$ vs. $36 \%)$ occurred in the two carrot seed lots following early spring planting (2 May 1990) in the field (Fig. 3A,
Table 3). Matriconditioning both seed lots with Micro-Ccl E reduced the time of emergence by 2.6 to 2.8 days, the $T_{50}$ of emergence by 2.1 to 3 days, and greatly increased the final emergence percentage when compared to the nonconditioned seeds. This effect was more pronounced in the older seed lot. Conditioning increased the final emergence percentage by $150 \%$ and 39\% in 'Nantes' and 'Long Imperator' carrot seeds, respectively. When the effect of conditioning on 'Long Imperator' and 'Nantes' seeds was compared, no differences were found in the $\mathrm{T}_{10}$ and $\mathrm{T}_{50}$ of emergence, but the final emergence percentage was higher in 'Long Imperator' than in 'Nantes' seeds $(50 \%$ vs. $35 \%)$. The addition of the fungicides metalaxyl and thiram during matriconditioning of 'Long Imperator' seeds reduced, to some extent, the promotive effect of conditioning on final emergence, but had no effect on $\mathrm{T}_{10}$ or $\mathrm{T}_{50}$ of emergence, suggesting that seed decay and root-rot pathogens played no significant role in stand establishment of carrot.

The improvements in performance of carrot seeds during early planting as a result of matriconditioning are similar to those 
Table 3. Computation of field emergence criteria and statistical significance from data in Fig. 3.'

\begin{tabular}{|c|c|c|c|c|c|c|}
\hline \multirow[b]{2}{*}{ Seed/cultivar/chemical } & \multicolumn{2}{|c|}{$T_{10}$ (days) } & \multicolumn{2}{|c|}{$T_{50}$ (days) } & \multicolumn{2}{|c|}{$\begin{array}{c}\text { Final emergence } \\
(\%)\end{array}$} \\
\hline & $\mathrm{Cy}^{\mathrm{y}}$ & $\mathrm{NC}$ & $\mathrm{C}$ & $\mathrm{NC}$ & $\mathrm{C}$ & $\mathrm{NC}$ \\
\hline \multicolumn{7}{|l|}{ Carrot } \\
\hline Long Imperator & 12.7 & 15.5 & 15.2 & 17.3 & 50 & 36 \\
\hline Long Imperator $(\mathrm{A}+\mathrm{T})$ & 12.8 & 15.5 & 15.5 & 17.6 & 42 & 35 \\
\hline Nantes & 13.0 & 15.6 & 15.0 & 18.0 & 35 & 14 \\
\hline Significance & \multirow{2}{*}{\multicolumn{2}{|c|}{ ** }} & \multirow{2}{*}{\multicolumn{2}{|c|}{ ** }} & \\
\hline C vs. NC Long Imperator & & & & & \multirow{2}{*}{\multicolumn{2}{|c|}{$\begin{array}{l}* * \\
* *\end{array}$}} \\
\hline C vs. NC Nantes & \multicolumn{2}{|c|}{ ** } & \multicolumn{2}{|c|}{ ** } & & \\
\hline C vs. $C(A+T)$ Long Imperator & \multicolumn{2}{|c|}{ NS } & \multicolumn{2}{|c|}{ NS } & \multicolumn{2}{|c|}{$*$} \\
\hline C Long Imperator vs. C Nantes & \multirow{2}{*}{\multicolumn{2}{|c|}{$\begin{array}{l}\text { NS } \\
\text { NS }\end{array}$}} & \multirow{2}{*}{\multicolumn{2}{|c|}{ NS }} & \multirow{2}{*}{\multicolumn{2}{|c|}{ ** }} \\
\hline NC Long Imperator vs. NC Nantes & & & & & & \\
\hline \multicolumn{7}{|l|}{ Tomato } \\
\hline Jackpot & 4.8 & 5.7 . & 10.4 & 9.3 & 54 & 29 \\
\hline Jackpot $(\mathrm{T})$ & 5.2 & 5.7 & 10.2 & 9.0 & 58 & 27 \\
\hline \multicolumn{7}{|l|}{ Significance } \\
\hline C vs. NC & \multicolumn{2}{|c|}{ ** } & \multicolumn{2}{|c|}{ NS } & \multicolumn{2}{|c|}{ ** } \\
\hline C vs. C (T) & \multicolumn{2}{|c|}{ NS } & \multirow{2}{*}{\multicolumn{2}{|c|}{ NS }} & \multirow{2}{*}{\multicolumn{2}{|c|}{ NS }} \\
\hline Pepper & & & & & & \\
\hline California Wonder & 12.5 & 14.0 & 16.2 & 17.7 & 44 & 34 \\
\hline California Wonder $(\mathrm{T})$ & 13.2 & 14.8 & 17.4 & 18.5 & 35 & 28 \\
\hline \multicolumn{7}{|l|}{ Significance } \\
\hline C vs. NC & \multicolumn{2}{|l|}{ ** } & \multicolumn{2}{|c|}{ ** } & \multicolumn{2}{|c|}{ * } \\
\hline C vs. C (T) & NS & & * & & , & \\
\hline Snap bean ${ }^{y}$ & & & & & & \\
\hline BBL 47 (L) & $5.9(\mathrm{M})$ & 6.7 & $6.9(\mathrm{M})$ & 7.7 & $66(\mathrm{M})$ & 75 \\
\hline BBL $47(\mathrm{GA}+\mathrm{L})$ & $5.1(\mathrm{M})$ & -- & $6.5(\mathrm{M})$ & -.- & $74(\mathrm{M})$ & --. \\
\hline BBL47 $(\mathrm{GA}+\mathrm{L})$ & 4.7 (V) & --. & $6.4(\mathrm{~V})$ & --- & $60(\mathrm{~V})$ & ... \\
\hline Significance & & & & & & \\
\hline$C(M+L)$ vs. $N C(L)$ & * & & ** & & * & \\
\hline$C(M+G A+L)$ vs. $N C(L)$ & ** & & ** & & $\mathbf{N}$ & \\
\hline $\mathrm{C}(\mathrm{V}+\mathrm{GA}+\mathrm{L})$ vs. NC (L) & ** & & ** & & * & \\
\hline$C(M+L)$ vs. $C(M+G A+L)$ & ** & & ** & & * & \\
\hline$C(M+G A+L)$ vs. $C(V+G A+L)$ & NS & & NS & & * & \\
\hline
\end{tabular}

${ }^{2}$ Notations for pesticides and carriers and GA, concentrations as in Fig. 3.

'Nonconditioned (NC) or conditioned (C) with Micro-Ccl E (M) and expanded vermiculite \#5 (V).

Ns, $*$,**,Significant at $P=0.05$ and 0.01 or nonsignificant, respectively.

reported for osmoconditioning (Szafirowska et al, 1981). In that study, as in the present one, a preplant conditioning improved the performance of good- and poor-quality seeds, and the improvements were greater in the poor-quality than in the more vigorous seeds. Thus, matriconditioning, like osmoconditioning, might influence metabolic repair of processes related to aging, as well as physiological and biochemical events associated with the rapidity and synchrony of germination and germination potential (Khan, 1991).

Matriconditioning of tomato seeds reduced the $\mathrm{T}_{10}$ of emergence by 0.9 day, had no significant effect on the $\mathrm{T}_{50}$ of emergence, and improved the final percent emergence by $86 \%$ when compared with nonconditioned seeds (Fig. 3B, Table 3). In pepper, matriconditioning reduced the $\mathrm{T}_{10}$ and $\mathrm{T}_{50}$ of emergence by 1.5 days and improved the final percent emergence by $30 \%$ (Fig. 3C, Table 3). In tomato, application of thiram to dry seeds or to seeds during conditioning had little effect on seedling emergence. In pepper, thiram inhibited the $\mathrm{T}_{50}$ of emergence and final emergence percentage to some extent. As with carrot, no symptoms of seed or seedling infection from soilborne pathogens were found in tomato and pepper. This might be due to a relatively dry period during early emergence (see Fig. 1), which would largely prevent seed and root rot. The relatively low final percent emergence in tomato and pepper, particularly in untreated seeds, could be due to injuries to young seedlings by low soil temperatures during the early part of June (Fig. 1).

Osmoconditioning of tomato seeds in PEG or salt solutions has been reported to shorten the emergence time of tomato in field plantings (Alvarado et al., 1987; Bussel and Gray, 1976). The effect on field emergence of pepper seeds has ranged from no improvement to some advancement in mean germination time (Bradford et al., 1990; Yaklitch and Orzolek, 1977). Our study indicates that matriconditioning in Micro-Ccl E, and perhaps other solid carriers, may be an effective way to shorten the time of emergence and increase stand establishment in both tomato and pepper.

Matriconditioning of snap bean seeds with Micro-Ccl E reduced the $T_{10}$ and the $T_{50}$ of emergence by 0.8 day. The final emergence percentage in conditioned seeds was, however, diminished significantly (66\% vs. $75 \%$ ) (Fig. 3D, Table 3). Treatment of seeds with $0.001 \mathrm{mM} \mathrm{GA}_{3}$ during matriconditioning with Micro-Ccl $\mathrm{E}$ reduced the $\mathrm{T}_{10}$ of emergence by 1.6 days, the $\mathrm{T}_{50}$ of emergence by 1.2 days, and restored the emergence percentage to the level found in nonconditioned seeds. Inclusion of $0.002 \mathrm{~mm} \mathrm{GA}_{3}$ during conditioning with expanded vermiculite \#5 adversely affected the final percent emergence $(60 \%$ vs. $75 \%$ ), even though the $T_{10}$ and the $T_{50}$ of emergence were similar to seeds matriconditioned with Micro-Ccl E in the pres- 
ence of $0.001 \mathrm{~mm} \mathrm{GA}_{3}$. A reduction in percentage emergence in conditioned snap bean seeds may be due to a high initial water content at the time of planting, which would make them susceptible to mechanical injury and soilborne diseases. A rapid emergence, and hence a shorter period of contact with the soil, of GA-treated seeds appears to partly circumvent this problem. Undoubtedly, further studies will be needed to integrate the advantages of GA and effective fungicides during matriconditioning to improve plant stand.

Snap bean seeds are susceptible to imbibitional and chilling injury (as are seeds of sweet corn, soybean, and cotton). No attempt, to our knowledge, has been made to improve emergence or yield of snap bean seeds by low-water-potential seed hydration treatments. Osmoconditioning of soybean seeds in PEG solution, although successful in improving emergence at cold temperatures in laboratory studies (Knypl and Khan, 1981), has given varied results in early spring plantings in the field (Helsel et al., 1986; Khan et al., 1980/81). Addition of GA during osmoconditioning of soybean seeds invariably reduced the emergence time, but percent emergence was decreased (Khan et al., 1980/81). Taken together, these studies indicate that lowwater-potential seed conditioning in the presence of a small amount of $\mathrm{GA}_{3}$ (which stimulates hypocotyl growth and, thus, emergence) may be a valid strategy to shorten the emergence time and improve plant stand in legumes. Large amounts of $\mathrm{GA}_{3}$ induce rapid emergence but produce stringy seedlings that lodge easily, thus affecting final stand.

Solid carriers, such as Micro-Ccl E and expanded vermiculite \#5, may be more suited than a liquid medium like PEG solution for preplant conditioning of seeds susceptible to imbibitional and chilling injury. This suggestion derives from studies with sweet corn, in which osmoconditioning with PEG was less effective in improving early emergence than was moisturizing seeds on vermiculite (Bennett and Waters, 1987). A direct contact with water, as during conditioning in PEG solution, may be harmful to seeds. Carriers, such as Micro-Ccl E and expanded vermiculite $\# 5$, with high water-retaining capacities and large surface areas may be more suited to integrate the physiological advantages of conditioning with a specific effect of a plant hormone or other useful chemicals.

Improved performance of conditioned seeds maybe due to a cumulative effect of a variety of physiological and biochemical events: 1) enhanced mobilization of seed reserves as a result of activation or synthesis of key enzymes (Fu et al., 1988; Khan et al., 1978), 2) accumulation of osmotically active substances as indicated by improved germination potential of seeds (Akers et al., 1987; Khan and Samimy, 1982), 3) cellular repair and improved integrity of the membrane as evidenced by a decrease in leakage of electrolytes in conditioned seeds (Argerich and Bradford, 1989; Burgass and Powell, 1984), and 4) a decrease in seed exudates that encourage fungal and bacterial growth on the seed surface (Osburn and Schroth, 1988).

Preplant conditioning of seeds with moist solid carriers, such as Micro-Ccl E and expanded vermiculite \#5, having low bulk densities, high porosity, large surface areas, diverse particle size and structure, and high water-holding capacities may have an advantage over solids with high bulk densities, low surface areas, and low water-holding capacities, particularly when controlling seed hydration over prolonged periods. The carriers used in this study have characteristics that, in addition to controlling seed hydration, would permit treating seeds with hormones, pesticides, nutrients, and biomolecules (Khan et al., 1990). The problem of high viscosity and low oxygen volubility in an os- moticum such as PEG, and the injury to seeds in various cases reported when using salt solutions as an osmoticum, can be overcome by conditioning seeds in relatively inert, water-insoluble carriers, such as Micro-Ccl E and expanded vermiculite \#5. In addition, the logistics of treating, handling, and transporting seeds in bulk may also favor solids over liquids as preplant conditioning media.

\section{Literature Cited}

Akers, S.W., G.A. Berkowitz, and J. Rabin. 1987. Germination of parsley seed primed in aerated solutions of polyethylene glycol. HortScience 22:250-252.

Alvarado, A. D., K.J. Bradford, and J.D. Hewitt. 1987. Osmotic priming of tomato seeds. Effects on germination, field emergence, seedling growth and fruit yield. J. Amer. Soc. Hort. Sci. 112:427432.

Argerich, A. and K.J. Bradford. 1989. The effects of priming and ageing on seed priming. J. Expt. Bet. 40:599-607.

Bennett, M.A. and L. Waters, Jr. 1987. Seed hydration treatments for improved sweet corn germination and stand establishment. J. Amer. Soc. Hort. Sci. 112:45-49.

Bradford, K.J. 1986. Manipulation of seed water relations via osmotic priming to improve germination under stress conditions. HortScience 21:1105-1112.

Bradford, K. J., J.J. Steiner, and S.E. Trawatha. 1990. Seed priming influence and emergence of pepper seed lots. Crop Sci. 30:718721.

Burgass, R.W. and A.A. Powell. 1984. Evidence for repair processes in the invigoration of seeds by hydration. Ann. Bet. 53:753-757.

Bussel, W.T. and D. Gray. 1976. Effects of pre-sowing seed treatments and temperatures on tomato (Lycopersicon esculentum) seed germination and seedling emergence. Scientia Hort. 5:101-109.

Callan, N.W., D.E. Mathre, and J.B. Miller. 1990. Bio-priming seed treatment for biological control of Pythium ultimum preemergence damping-off in sh2 sweet corn. Plant Dis. 74:368-372.

Fu, J. R., X.H. Lu, R.Z. Chen, B.Z. Zhang, Z.S. Li, and D.Y. Cay. 1988. Osmoconditioning of peanut (Arachis hypogea L.) seeds with PEG to improve vigor and some biochemical activities. Seed Sci. Technol. 16:197-212.

Harman, G. E., A.G. Taylor, and T.E. Statz. 1989. Combining effective strains of Trichderma harzianum and solid matrix priming to improve biological seed treatments. Plant Dis. 73:631-637.

Helsel, D., D.R. Helsel, and H.C. Minor. 1986. Field studies on osmoconditioning soybeans, Glycine max. Field Crops Res. 14:291298.

Heydecker, W. and P. Coolbear. 1977. Seed treatments for improved performance-survey and attempted prognosis. Seed Sci. Technol. $5: 353425$

Khan, A.A. 1991. Preplant physiological seed conditioning. Hort. Rev. (In press.)

Khan, A.A. and J.D. Maguire. 1990. Isolation of vegetable seeds by semi-permeable membrane during matriconditioning. HortScience 25:1156. (Abstr.)

Khan, A. A., H. Miura, J. Prusinski, and S. Ilyas. 1990. Matriconditioning of seeds to improve performance, p. 1940. Proc. Natl. Symp. Stand Establishment Hort. Crops, Minneapolis.

Khan, A. A., N.H. Peck, and C. Samimy. 1980/81. Seed osmoconditioning: Physiological and biochemical changes. Isr. J. Bet. 29:133144.

Khan, A.A. and C. Samimy. 1982. Hormones in relation to primary and secondary seed dormancy, p. 203-241. In: A.A. Khan (cd.). The physiology and biochemistry of seed development, dormancy, and germination. Elsevier, Amsterdam.

Khan, A.A., K.-L. Tao, J.S. Knypl, B. Borkowska, and L.E. Powell. 1978. Osmotic conditioning of seeds: Physiological and biochemical changes. Acts Hort. 83:267-278.

Khan, A.A. and A.G. Taylor. 1986. Polyethylene glycol incorporation in table beet seed pellets to improve emergence and yield in wet soil. HortScience 21:987-989. 
Knypl, J.S. and A.A. Khan. 1981. Osmoconditioning of soybean seeds to improve performance at suboptimal temperatures. Agron. J. 73:112116.

Kubik, K. K., J.A. Eastin, J.D. Eastin, and K.M. Eskridge. 1988. Solid matrix priming of tomato and pepper, p. 86-96. Proc. Intl. Conf. Stand Establishment Hort. Crops, Lancaster, Pa.

Olson, K.R. 1979. Saran coated method for determining bulk densities, soil moisture values, and linear extensibility. Agron. Mimeogr. 795, Soil Characterization Lab., Cornell Univ., Ithaca, N.Y.

Osbum, R.M. and M.N. Schroth. 1988. Effect of osmopriming sugar beet seed on germination rate and incidence of Pythium ultimum damping-off. Plant Dis. 73:21-24.

Parera, C.A. and D.J. Cantliffe. 1990. Improved stand establishment of $s h 2$ sweet com by solid matrix priming and seed disinfection treatments, p. 91-96. Proc. Natl. Symp. Stand Establishment Hort. Crops, Minneapolis.

Peterson, J.R. 1976. Osmotic priming of onion seeds-The possibility of a commercial scale treatment. Scientia Hort. 5:207-214.

Szafirowska, A., A.A. Khan, and N.H. Peck. 1981. Osmoconditioning of carrot seeds to improve seedling establishment and yield in cold soil. Agron. J. 73:845-848.

Taylor, A. G., D.E. Klein, and T.H. Whitlow. 1988. SMP: Solid matrix priming of seeds. Scientia Hort. 37:1-11.

Yaklitch, R.W. and M.D. Orzolek. 1977. Effect of polyethylene glycol-6000 on pepper seed. HortScience 12263-264.

Zuo, W., C. Chang, and G. Zheng. 1988. Effects of osmotic priming with sodium polypropionate (SPP) on seed germination, p. 114-123. Proc. Intl. Conf. Stand Establishment Hort. Crops, Lancaster, Pa. 